http://dx.doi.org/10.1590/0370-44672017710183

\begin{abstract}
João Alberto de Souza Nunes
Engenheiro da Acumuladores Moura SA

Belo Jardim - Pernambuco - Brasil

joao.alberto.nunes@hotmail.com
\end{abstract}

Carlos Adolpho Magalhães Baltar

http://orcid.org/0000-0001-8844-6928

Professor-Titular

Universidade Federal de Pernambuco - UFPE

Departamento de Engenharia de Minas

Recife - Pernambuco - Brasil

camb@ufpe.br

\section{Luiz Carlos Bertolino}

Pesquisador

Centro de Tecnologia Mineral

Rio de Janeiro - Rio de Janeiro - Brasil

Icbertolino@cetem.gov.br

\section{Bianca Maria da Silva}

Estagiária

Acumuladores Moura

Recife - Pernambuco - Brasil

biancasilva229@gmail.com

\section{Introduction}

Most of the lead consumed in Brazil comes from the recycling of automotive, industrial and telecommunication batteries (Teixeira \& Silva, 2015). Secondary lead is obtained from recycling of leadacid battery scrap. The scrap is composed of five components: the active material $\left(\mathrm{PbSO}_{4}, \mathrm{PbO}\right.$ and $\left.\mathrm{PbO}_{2}\right)$, metallic lead,

\title{
SEM study of a lead-iron slag flotation process
}

Abstract

Companies producing lead-acid batteries are required by law to recycle their battery scrap. The recycling can be performed by a pyrometallurgical process resulting in slags containing mainly lead and iron. A study was carried out with the aim of recovering the lead contained in this slag. This work has economic and environmental implications. Slag characterization was performed by X-ray diffraction, X-ray fluorescence and scanning electron microscopy (SEM). A laboratory-scale mechanical cell was used for flotation tests. The results showed that $\mathrm{Pb}$-Fe selectivity is possible using ethyl xanthate as collector. The coke floats together decreasing concentrate grade. However, this is no problem because coke participates in the metallurgical process for the production of lead. A concentrate containing $22.9 \% \mathrm{~Pb}$ was obtained from a slag with $2.2 \% \mathrm{~Pb}$. The process removes more than $99.6 \%$ of the iron contained. However, the recovery was only $19.0 \%$. Analyses from scanning electron microscopy detected the presence of lead inside the iron particles, limiting the possibility of lead recovery.

Keywords: SEM application, slag flotation, lead flotation, iron-lead separation, lead recovery.

sulfuric acid, plastic and separator (polypropylene and $\mathrm{SiO}_{2}$ ). Figure 1 shows the approximate composition of a lead-acid battery scrap.

The recycling process consists of three steps: dismantling of the battery, separation of its components (active material, metallic lead, plastic, sulfuric acid and separators), and lead production in a rotary furnace. Metallic lead is fed to the furnace with other lead compounds (active material), iron scrap (Fe source), coke (C source) and soda ash (fluxing agent). It is then processed in batches for seven hours with temperatures up to $1000{ }^{\circ} \mathrm{C}$ (Nunes, 2015).

Figure 1

Approximate composition

of lead-acid battery scrap (Nunes, 2015).

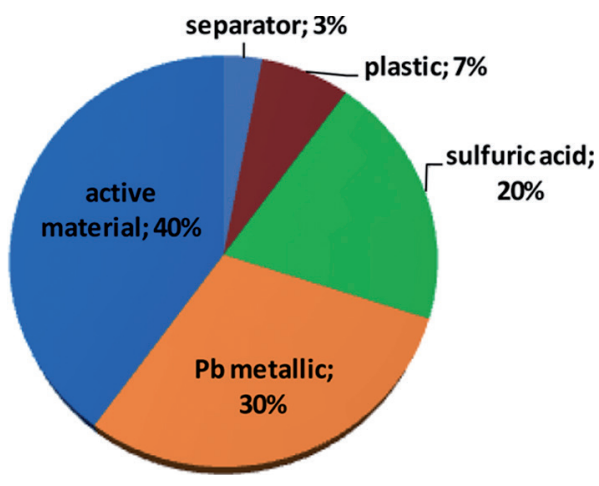

According to Queneau et al. (1989) the following overall reaction takes place in furnaces:

$$
\begin{array}{r}
2 \mathrm{PbSO}_{4(\mathrm{I})}+\mathrm{Na}_{2} \mathrm{CO}_{3(\mathrm{I})}+\mathrm{Fe}(\mathrm{s})+9 \mathrm{C}_{(\mathrm{s})} \stackrel{\Delta}{\rightarrow} 2 \mathrm{~Pb}_{(\mathrm{I})}+\mathrm{FeS}_{\mathrm{Na}} \mathrm{S}_{(\mathrm{I})}+9 \mathrm{CO}_{(\mathrm{g})}+\mathrm{CO}_{2(\mathrm{~g})} \\
\text { REM, Int. Eng. J., Ouro Preto, 71(3), 471-476, jul. sep. | } 2018
\end{array}
$$


First, occurs the conversion of lead sulfate to lead sulfide by the addition of carbon as indicated in Eq. (2):

$$
\left.\mathrm{PbSO}_{4(\mathrm{l})}+2 \mathrm{C}_{(\mathrm{s}}\right) \stackrel{\Delta}{\rightarrow} \mathrm{PbS}_{(\mathrm{l})}+2 \mathrm{CO}_{2(\mathrm{~g})}
$$

Then, the iron added as scrap reduces lead sulfide to metallic lead as shown in Eq. (3):

$$
\mathrm{PbS}_{(\mathrm{l})}+\mathrm{Fe}_{(\mathrm{s})} \stackrel{\Delta}{\rightarrow} \mathrm{Pb}_{(\mathrm{I})}+\mathrm{FeS}_{(\mathrm{l})}
$$

Lead oxide compounds, from the active material, react with carbon to pro-

Following chemical reactions in the furnace, two distinct phases are formed; one with higher density (metallic lead) and another with lower density (slag). Both metallic lead and slag are removed from the furnace at
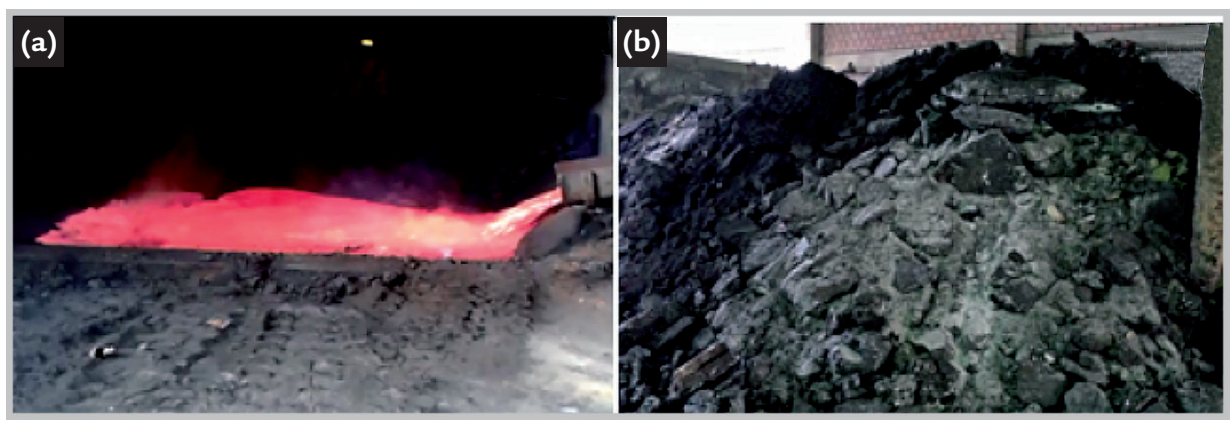

The objective of the research was to verify the possibility of developing a flotation process for the recovery of lead contained in a metallurgical slag (consisting mainly of iron + lead). The slag is generated by the industrial metallurgical process used at Acumuladores Moura Company for recycling used batteries. Froth flotation is the main and most widely used technique for mineral processing; it is based on the differences in the physicochemical surface properties of the minerals, without regard to their interior. The study reached an apparently selective process for the concentration of lead particles (which can be clearly seen in Figure 5 by the color difference of the products). This process eliminates $99.6 \%$ of the iron. However, the recovery of lead is very low. The low lead recovery was difficult of understanding considering that by "naked eye" or by microscopic analysis seems that are an insignificant amount of lead particles in the iron waste. The understanding of the phenomenon was only possible by the SEM analyses that showed the presence of lead inside iron particles. Therefore, this "hidden" lead would be unattainable to flota- duce metallic lead according Eqs. (4) and (5) (Nunes, 2015):

$$
\begin{aligned}
& \mathrm{PbO}_{2(\mathrm{I})}+\mathrm{C}(\mathrm{s}) \stackrel{\Delta}{\rightarrow} \mathrm{CO}_{(\mathrm{g})}+\mathrm{PbO}_{(\mathrm{I})} \\
& \left.2 \mathrm{PbO}_{(\mathrm{l})}+\mathrm{C}_{(\mathrm{s})}\right) \stackrel{\Delta}{\rightarrow} \mathrm{CO}_{2(\mathrm{~g})}+2 \mathrm{~Pb}_{(\mathrm{l})}
\end{aligned}
$$

temperatures above their melting points (Figure 2a).

A pyrometallurgical process typically allows a $93 \%$ to $97 \%$ recovery of the lead contained in the scrap. The remaining lead is lost in the slag, a residue which constitutes about $20 \%$ to $25 \%$ of the total furnace-feeding load (Nunes, 2015). After the solidification process, slags are stored in enclosed areas for 40 days for the natural breakdown process (Figure 2b).
Figure 2

The metallurgical slag used in the study: (a) at the furnace output (liquid) and (b) on the natural breakdown process during its storage period.

tion and explains the low metallurgical recovery. The result of this study becomes very important because this phenomenon (which is not observed in a liberated mineral particle) probably occurs in other slags and, therefore, warns to the difficulty of using ore concentration techniques for the recovery of metals contained in slags.

There are few articles related to the flotation of iron-lead slag and none of them refers to the use of SEM analysis in order to investigate the interior of the particles. Most of previous studies with slag flotation have noted the need for fine grinding for liberation the metal of interest (Roy et al., 2015; Szépvölgyi et al., 1988) and generally, flotation results in low grade concentrates (ROY et al., 2015; Sarrafi et al., 2004). Roy et al. (2015) tested different mixtures of collectors for the flotation of a slag containing copper, iron and silicon. The authors pointed out the need for fine grinding $\left(\mathrm{d}_{80}=75 \mu \mathrm{m}\right)$ for copper particles liberation. Using a mixture of isopropyl xanthate and dithiophosphate, a recovery of $84.8 \%$ was achieved. However, the concentrate grade stayed below $18 \%$ Cu. Szépvölgyi et al. (1988) used sodium sulfide and xanthate for the flotation of a polymetallic slag containing tin, lead, and copper. The sample was ground to less than $45 \mu \mathrm{m}$ to allow for a bulk metal liberation. A concentrate containing only $19.5 \% \mathrm{~Pb}, 20.2 \% \mathrm{Sn}$ and $12.0 \% \mathrm{Cu}$ was achieved. Sarrafi et al. (2004) obtained a $72 \%$ copper recovery from a metallurgical slag by using a mercaptobenzothiazole. However, the concentrate grade was only $12.6 \% \mathrm{Cu}$. The authors noted a strong influence of the slag cooling rate on the flotation results. The best results were obtained employing slow cooling rates. After discarding the fine fraction (less than $37 \mu \mathrm{m})$, Braga et al. (2012) used a process with both gravit separation (by vibratory table) and flotation. The authors achieved concentrate grade of $57.6 \% \mathrm{~Pb}$ and $26.3 \mathrm{~b} \%$ recovery, from a slag containing $9.8 \% \mathrm{PbO}$.

Lead sulphide ore flotation is carried out with ethyl xanthate, once the stability of the compound formed on the galena surface is sufficient even with short chain xanthates. Considering that galena $(\mathrm{PbS})$ rest potential is less than the xanthate oxidation potential (Alison et al., 1972), 
hydrophobic coating on galena surface occurs through the collector chemisorption via ionic substitution (Buckley et

\section{Materials and methods}

The slag sample used came from the metallurgical plant of the company Acumuladores Moura S/A. The furnace load consists of battery residues (including metallic lead) and the reagents added, namely iron (scrap), carbon (coke), and sodium carbonate.

The collectors used were sodium xanthates provided by SNF FLOMIN. The frothers methyl-isobutyl-carbinol (MIBC) and polyglycol were supplied by PIETSCHEMICALS and SNF FLOMIN, respectively. The sodium sulfide was produced by CROMATO PRODUTOS QUIMICOS. Sodium hydroxide $(\mathrm{NaOH})$ or sulfuric acid $\left(\mathrm{H}_{2} \mathrm{SO}_{4}\right)$ was used for the $\mathrm{pH}$ adjustments.

A jaw crusher and a cylindrical ball mill (U. S. AKRON STOMEWARE (90H110) were used for sample grinding. Flotation experi-

\section{Results and discussion}

\subsection{Slag characterization}

The results of the XRD analyze showed phases containing mainly iron

Figure 3

X-ray diffraction patterns of different slag fractions. Co K $\alpha(40 \mathrm{kV} / 40 \mathrm{~mA})$ radiation. $\mathrm{G}$ - galena, $\mathrm{Q}$ - quartz, $\mathrm{W}$ - wickenburgit, $\mathrm{C}$ - calcite, $\mathrm{M}$ - magnetite.

According to X-ray fluorescence analysis, the sample contains $\mathrm{Fe}_{2} \mathrm{O}_{3}$ (40.3\%), $\mathrm{SO}_{3}(26.4 \%), \mathrm{Na}_{2} \mathrm{O}(15.0 \%)$ and $\mathrm{PbO}(5.0 \%)$ as the main elements.

Images from scanning electron al,. 2003; Vučinić et al., 2006). Flotation of oxidized lead ores, such as cerussite $\left(\mathrm{PbCO}_{3}\right)$, requires activation with sodium

ments were performed at a lab-scale DENVER Sub-A flotation cell. The experiments followed the standard procedure with froth removal every 15 seconds. All flotation tests were carried out with $300 \mathrm{~g}$ of sample. The particles size was fixed by sieving in the range 38-104 $\mu \mathrm{m}$. The sample was initially washed in distilled water to eliminate part of the dissolved ions. After washing, the conductivity of the pulp, with $10 \%$ solids (by weight), had between 300 and $400 \mu \mathrm{s} / \mathrm{cm}$. An INOLAB conductivity meter, model WTW, was used for monitoring the dissolved species in the pulp. The collector was added after $\mathrm{pH}$ adjustment and conditioned for 15 minutes, whereupon the frother was added and the air released to start flotation. The impeller speed of the flotation cell was maintained at $1200 \mathrm{rpm}$. The sulphide prior to the thiol collector addition (Herrera-Urbina et al., 1999; Önal et al., 2005). chemical analyses were performed by atomic absorption spectrophotometry at the laboratory of the Acumuladores Moura.

In order to characterize the slag in regard to size distribution, chemical composition and crystallographic phases present in the slag were used: (1) a Vibratory Screening apparatus, using a Tyler series set of sieves; (2) an X-ray Fluorescence Spectrometer - PANalycal, model AXIOS ADVANCED; (3) An X-ray Diffractometer (XRD) - BRUKER D4; (4) a Scanning Electron Microscopy (SEM) - FEI-BRUKER, model Quanta 400; and (5) a Petrographic Microscope.

The samples for MEV were metalized with carbon and analyzed in modules of secondary electrons, backscattered electrons and EDS and (5) a petrographic microscope. oxides and lead sulphide. It is noted in Figure 3 that there is homogeneity in composition with respect to size.

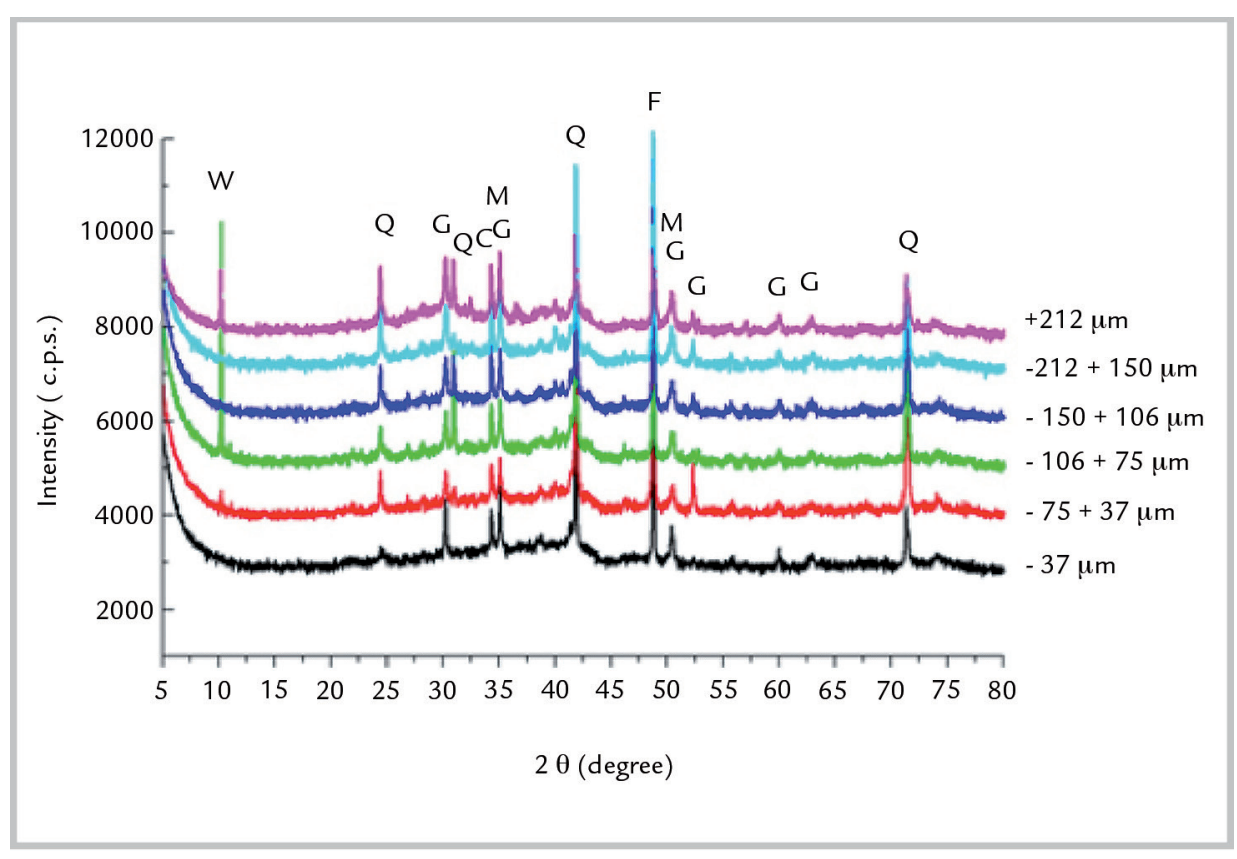

microscope (Figure 4) showed free (or isolated) lead particles with different sizes $(-106$ +75 mm; -150 +106 mm; -212 +150 $\mathrm{mm}$; and $+212 \mathrm{~mm})$. Lead particles can be identified by their lighter coloration.
The relative quantity of lead particles was similar in all size fractions, indicating that the material doesn't have a preferential distribution by size. As a result no size range of the slag can be rejected before flotation. 

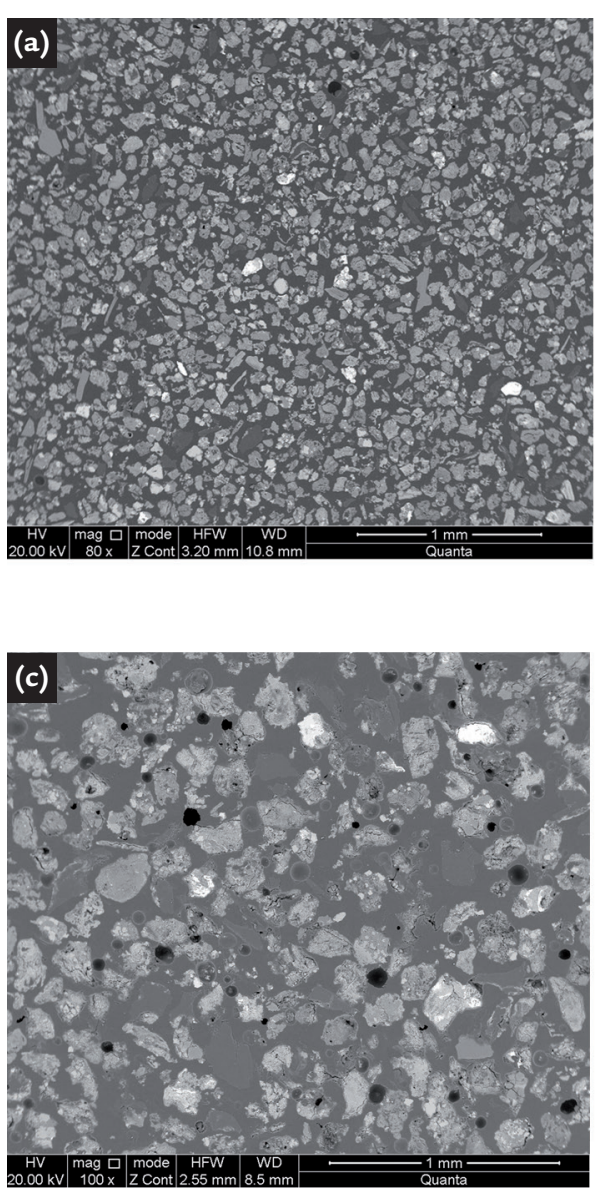

\subsection{Flotation}

Different collectors were tested for lead particles: fatty acids, amine, sodium dodecyl sulfate, sulfosuccinamate and xanthate. The xanthates presented the best potential for selectivity. No selectivity was observed in the tests with the other collectors.

A complication concerning to slag flotation is related to the ease release of ionic species from the particle surface to
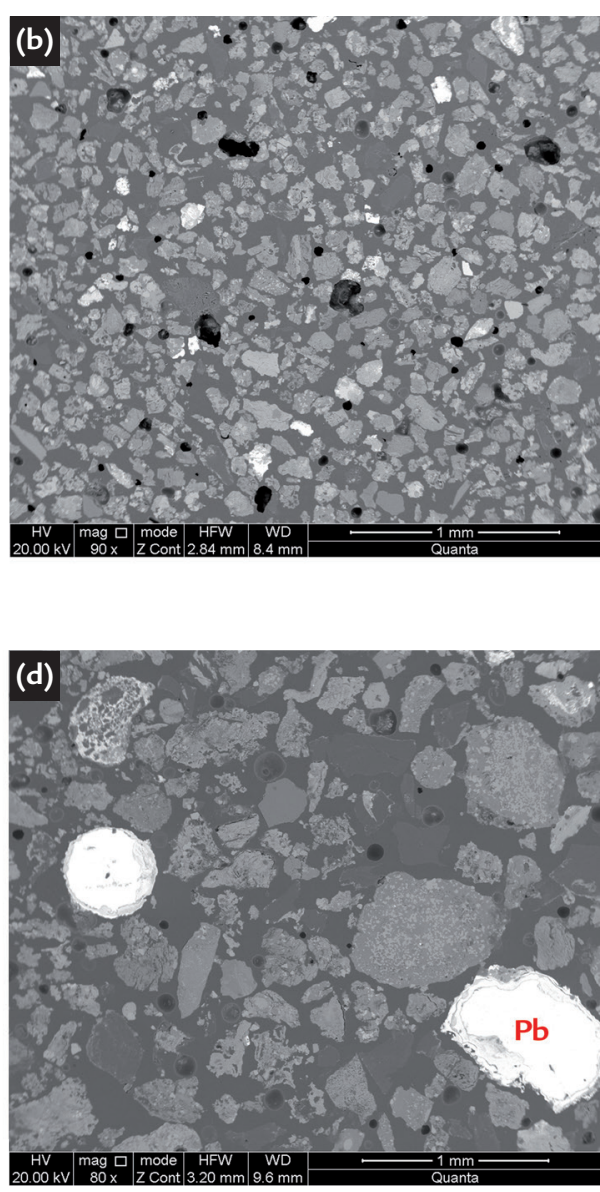

the liquid phase causing contamination in the process water. The presence of these ions in solution may cause collector precipitation (Rao \& Finch, 1989) or undesirable depression/activation (Liu et al., 2013). Once in contact with the slag, the conductivity of the distilled water used in flotation tests increase from $5 \mu \mathrm{s} / \mathrm{cm}$ to $10,110 \mu \mathrm{s} / \mathrm{cm}$. The removal of these ionic species is crucial
Figure 4

Images of the slag at different size fractions with backscattered electrons. (a) $-106+75 \mathrm{~mm}$, (b) $-150+106 \mathrm{~mm}$, $-212+150 \mathrm{~mm},(\mathrm{c})+212 \mathrm{~mm}$.

for lead flotation. Selectivity was only achieved in pulps with conductivity up to $220 \mu \mathrm{s} / \mathrm{cm}$. Table 1 shows the influence of collector concentration in slag flotation with ethyl xanthate at $\mathrm{pH} 9.5$. From a slag sample with $2.2 \% \mathrm{~Pb}$, it is possible to reach a grade of $22.9 \% \mathrm{~Pb}$ in the concentrate. The selectivity in the lead-iron separation can be observed in the Figure 5.

Table 1

Influence of ethyl xanthate concentration in slag flotation.

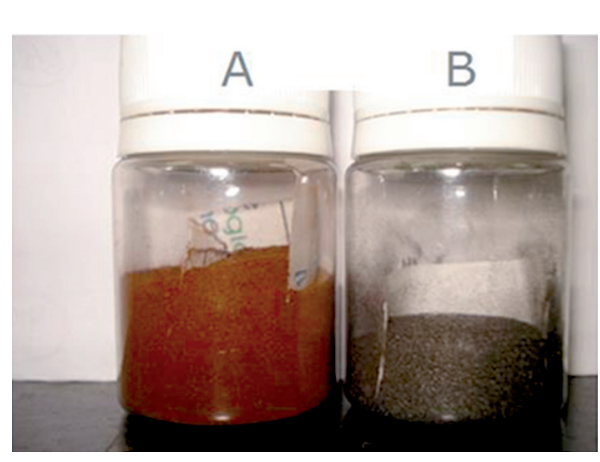

\begin{tabular}{c|c|c|c|c|c|c}
\multirow{2}{*}{ COLLECTOR $(\mathrm{g} / \mathrm{t})$} & \multicolumn{4}{|c|}{ SAMPLE } & \multicolumn{2}{c}{ RECOVERY } \\
\cline { 2 - 7 } & \multicolumn{2}{|c|}{ Feed } & \multicolumn{2}{c|}{ Concentrate } & $\mathrm{Pb}(\%)$ & $\mathrm{Fe}(\%)$ \\
\cline { 2 - 7 } & $\mathrm{Pb}(\%)$ & $\mathrm{Fe}(\%)$ & $\mathrm{Pb}(\%)$ & $\mathrm{Fe}(\%)$ & & \\
\hline 100 & 2.3 & 22.9 & 5.1 & 8.9 & 7.7 & 1.4 \\
\hline 200 & 2.2 & 25.2 & 9.5 & 9.8 & 15.8 & 1.4 \\
\hline 500 & 2.0 & 26.4 & 19.1 & 7.5 & 7.6 & 0.2 \\
\hline 750 & 2.2 & 26.1 & 22.9 & 6.0 & 19.0 & 0.4 \\
\hline
\end{tabular}

Figure 5

Concentrate $(A)$ and tailing (B) obtained from slag flotation with ethyl xanthate at $\mathrm{pH}$ 9.5. 
Chemical analysis revealed a carbon content of $47.5 \%$ in the concentrate which explains the difficulty in reaching higher lead grade. However, the carbon does not constitute a problem, since it is a reagent (as coke) in the metallic lead production process.

\section{Figure 6}

The influence of the xanthate chain lenght in slag flotation at $\mathrm{pH} 9.5$ and 750 g.t $\mathrm{t}^{-1}$ of collector.

Scanning electron microscopy (SEM) was used to investigate the difficulty found with increasing recovery.

Figure 7

Image of the cross section showing the presence of lead (light) inside the hydrophilic iron grain $(-150+106 \mathrm{~m})$.

\section{Conclusion}

Recovery of slag produced in the lead recycling process has economic and environmental implications. This work investigated the possibility of recovering the lead contained in the slag by flotation, the most efficient mineral processing technique. Slag flotation is difficult due to variations in particle surface characteristics as compared to more stable mineral surfaces.

The lead-iron selectivity was achieved using ethyl xanthate as collector. The concentrate contains $22.9 \% \mathrm{~Pb}$ and only $6.0 \% \mathrm{Fe}$. The process eliminates

\section{Acknowledgments}

The authors are thankful to Deborah Daiana, Rafael Ferrari, Leila Baltar
The flotation results indicate a very low recovery for lead. In order to enhance recovery, three possibilities were tested: (1) increase of the collector conditioning time, (2) use of sodium sulfide as activator, and (3) use of a xanthate with greater chain size. Results from attempts (1) and (2) were unsatisfactory. However, a recovery of $32.9 \%$ was achieved using amyl xanthate (Figure 6) at the cost of a reduction of the grade to $15.5 \% \mathrm{~Pb}$. Despite the selectivity achieved with amyl xanthate, the lead recovery remained low.

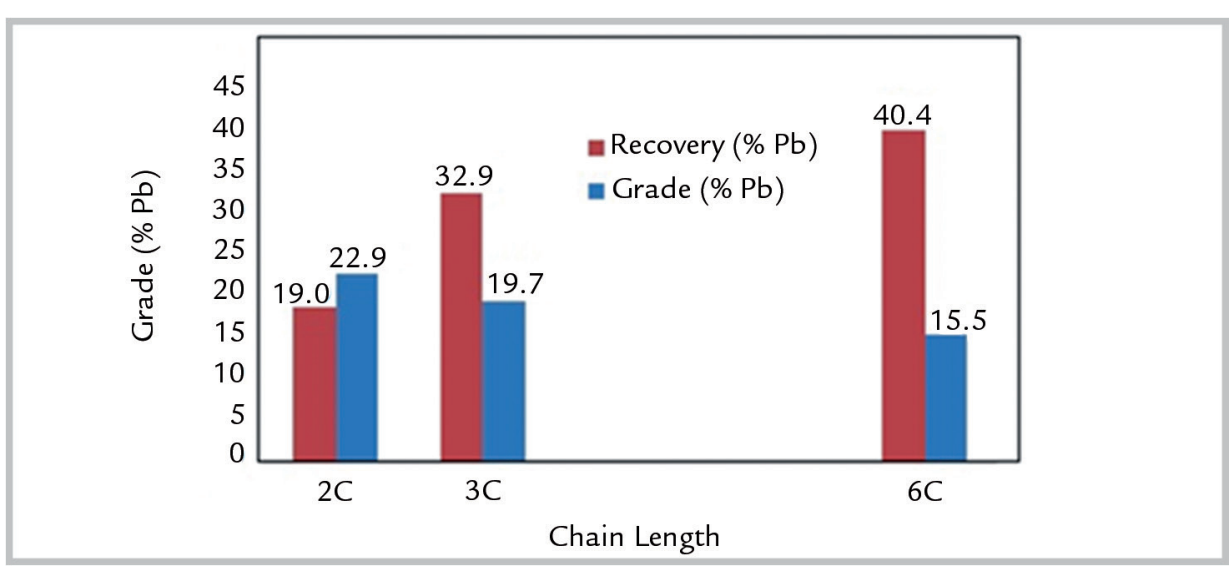

Iron particles were sectioned to obtain internal images. The images showed that a lead portion rests inside the hydrophilic

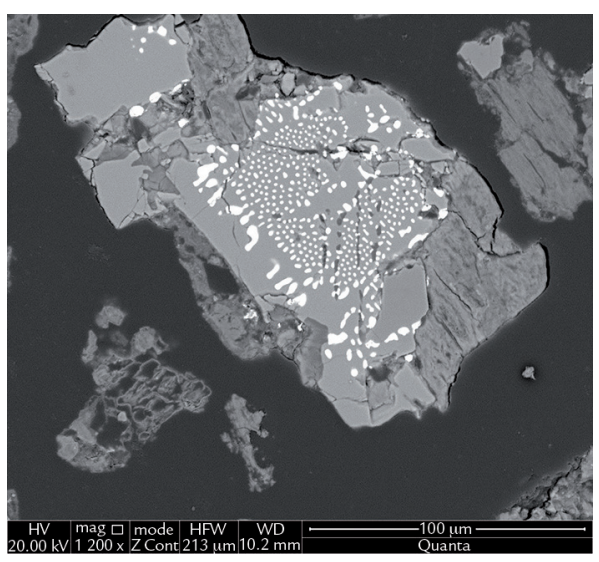

$99.6 \%$ of the iron contained in the flotation feed. However, the metallurgical lead recovery was only $19.0 \%$. A maximum lead recovery of $32.9 \%$ was achieved with amyl xanthate. The coke floats with lead decreasing the concentrate grade. However, this is not a problem because the carbon can be reused as a reagent in lead metallurgy. Analysis of the flotation concentrate through SEM showed that a greater recovery was not possible due to the presence of lead inside the iron particles.

Flotation separation is based on iron grains (Figure 7), which explains why it is not possible to get good recovery in lead flotation. and Marcelo Gomes for support in experimental stage. differences in surface properties not considering the inside of the particles. Although the process achieves a selective adsorption of the collector on lead particle surfaces (eliminating $99.6 \%$ wt. of the iron), and visually it seemed a perfect separation, the recovery was always very low. The discovery of lead inside the iron particles elucidated the mystery of "good separation" with low recovery. The result of the study is important because this can occur with other slags and, as it does not occur in the flotation of ores, it is a little-known phenomenon. 


\section{References}

ALLISON, S.A., GOOLD, L.A., NICOL, M.J., GRANVILLE, A. A determination of the products of reaction between various sulfide minerals and aqueous xanthate solution, and a correlation of the products with electrode rest potentials. Metallurgical Transactions, v. 3, p. 2613-2618, 1972.

BRAGA, P.F.A., SAMPAIO, J.A., BALTAR, C.A.M., COELHO, A.M., NUNES, J.A.S. Lead recovery from metallurgical slag by flotation. In INTERNATIONAL MINERAL PROCESSING CONFERENCE, 9, 2012. Santiago, Chile. p. 1-7, 2012.

BUCKLEY, A.N., GOH, S.W., LAMB, R.N., WOODS, R. Interaction of thiol collectors with pre-oxidised sulfide minerals. International Journal of Mineral Processing, 72, p. 163-174, 2003.

HERRERA-URBINA, R., SOTILLO, F.J., FUERSTENAU, D.W. Effect of sodium sulfide additions on the pulp potential and amyl xanthate flotation of cerussite and galena. International Journal of Mineral Processing, p. 157-170, 2013.

LIU, W., MORAN, C.J., VINK, S. A review of the effect of water quality on flotation. Minerals Engineering, v. 53, p. 91-100, 2013.

NUNES, J. A. S. Lead recovery from metallurgical slag through flotation. Recife: Federal University of Pernambuco, 2015. 117 p. (Doctoral Thesis - In Portuguese).

ÖNAL, G., BULUT, G., GÜL, A., KANGAL, O., PEREK, K.T., ARSLAN, F. Flotation of Aladag oxide lead-zinc ores. Minerals Engineering, v. 18, p. 279-282, 2005.

QUENEAU, P. B., CREGAR, D. E., MICKEY, D. K. Optimizing matte and slag in rotary furnace smelting of lead residues. In: Primary and Secundary Lead Processing. New York: Pergamon Press, 1989. p. 145-178.

RAO, S.R., FINCH, J.A. A review of water re-use in flotation. Minerals Engineering, v. 2, n. 1, p. 65-85, 1989.

ROY, S., DATTA, A., REHANI, S. Flotation of copper sulphide from copper smelter slag using multiple collectors and their mixtures. International Journal of Mineral Processing, v. 143, p. 43-49, 2015.

SARRAFI, A., RAHMATI, B., HASSANI, H.R., SHIRAZI, H.H.A. Recovery of copper from reverberatory furnace slag by flotation. Minerals Engineering, v. 17, p. 457-459, 2004.

SZÉPVÖLGYI, J., BERTÓTI, I., VARGA, I., MOHAI, M., SZÉKELY, T., PÁRKÁNYI, I. Studies on the flotation of a non-ferrous slag. Minerals Engineering, v.1, n.2, p. 127-136, 1988.

TEIXEIRA, J.A.A.B., SILVA, O.A. Chumbo. Sumário Mineral 2015. Departamento Nacional da Produção Mineral (DNPM), p. 44-45. (In Portuguese).

VUČINIĆ, D.R., LAZİC, P.M., ROSIC, A.A. (2006). Ethyl xanthate adsorption kinetics on lead-modified galena and sphalerite under flotation conditions. Colloids and Surfaces A, v. 279, p. 96-104.

Received: 12 December 2017 - Accepted: 18 April 2018. 